\title{
Wage Differentials, Monopsony Labor Markets, and the Trade-Labor Standards Debate
}

\author{
Robert C. Shelburne \\ U.S. Department of Labor
}

\begin{abstract}
This paper uses a simple theoretical model confined to reasonable parameters to investigate the implications of improved labor rights and benefits (i.e., standards) in the export sectors of the developing nations (the South). Given the strong opposition to a broad trade-labor linkage, it is likely that any externally imposed improved labor standards will be restricted to trade-impacted goods. That being the case, the only standards that are likely to significantly impact trade are improved union rights and living wage campaigns. The effects of improving these labor standards vary depending on whether initially there is a wage differential that the standard reduces or whether the standard creates a new differential. The degree to which an existing differential is due to monopsonistic labor markets is also important. It is found that if a standard improves worker welfare in one region, that it reduces worker welfare in the other region; thus improving labor standards effectively pits workers in the South against workers in the North. An exception to this is possible under certain monopsony situations. In what is the most realistic case, implementation of the labor standard improves the welfare of Northern workers and lowers the welfare of Southern workers. If the objective is to improve Northern workers' welfare, a Northern tariff is a more efficient policy tool than is a higher Southern labor standard.
\end{abstract}

- JEL Classifications : F13, J31, J24, C58

- Key words : Labor standards, Wage differentials, Monopsony

\footnotetext{
*Corresponding address: Doctor Robert C. Shelburne, Room South 5317, U.S. Labor Department, 200 Constitution Ave., NW Washington DC 20210 Tel: 202-693-4914 E-mail: shelburne-robert@dol.gov (C2004-Center for International Economics, Sejong Institution, All Rights Reserved.
} 


\section{Introduction}

Limited worker rights in many developing nations (the South) have raised concerns about the welfare of workers -- both the welfare of workers in the South who work under these conditions and the welfare of developed nations' (Northern) workers who must compete through trade with these Southern workers. These concerns have manifested themselves through several different channels. Foremost has been the effort of labor activists to incorporate a set of minimum labor standards into trade agreements, which would allow trade sanctions against products produced in nations with unacceptable standards. Disagreement about a role for a trade-labor linkage was an important factor in delaying a new round of trade liberalization under the auspices of the World Trade Organization (WTO). Debate about this issue was also an important factor in delaying the passage of fast-track authority in the United States. In addition, there is an ongoing "grassroots" movement by labor unions, student activists, and anti-globalization protesters to raise wages through living wage campaigns for Southern workers producing items exported to the industrialized world.

One of the difficulties in attempting to evaluate the impact of improving Southern labor standards has been the difficulty of specifying precisely what their economic effects would be. This is due to the fact that the proposals address a number of issues, and with several of these, it is not conceptually clear as to how they should be modeled so as to understand their implications. Much of the debate about labor standards has focused on the "core labor standards" which address the freedom of association and collective bargaining (basically the right to unionize), child labor, forced labor, and acceptable working conditions. ${ }^{1}$ Given that each of these is likely to have a significantly different economic effect, it is difficult to discuss their effects in their totality. Unions and/or acceptable working conditions have been modeled several ways but the approach taken here is to assume that they create a wage differential. Child labor and forced labor are probably best modeled as endowment changes. ${ }^{2}$

If there is a trade-labor linkage at either the multilateral or bilateral level, the

\footnotetext{
'The ILO definition of core labor standards includes discrimination while the United States Trade Act of 2002 replaced discrimination with "acceptable conditions of work with respect to minimum wages, hours of work, and occupational safety and health." ${ }^{2}$ The effects of any discrimination provision would depend critically on how it is interpreted; the legal
definition of discrimination is likely to differ from the purely economic definition.
} 
linkage is likely to be applicable only for trade-impacted goods. This outcome is most obvious with the living wage campaigns whose primary focus is on increasing wages at the exporting plants of multinational corporations and not on increasing national minimum wages. As for introducing the core standards into trade agreements or into the structure of the WTO, it is also likely that only tradeimpacted goods will be covered. To some degree this is a political retreat by labor activists who have generally concluded that any broad trade-labor linkage is not politically viable, and have therefore attempted to make this linkage more politically palatable by proposing that enforcement should be restricted to only violations that impact trade. The limitation of sanctions or fines to only tradeimpacted goods is already present in several existing bilateral trade agreements where there is some mention of labor standards. This is the case with the North American Agreement on Labor Co-operation under the NAFTA as well as the Canada-Chile free trade agreement (Elliott, 2001). Morici and Schulz (2001), in proposing WTO reform, propose trade sanctions not for violations of labor standards generally, but only for those that negatively impact another country through trade. Elliott (2001) also recommends that any labor standards agreement "focus narrowly on trade-related violations." The focus on a trade impact is also consistent with the fact that Northern unions are the primary advocates of a tradelabor linkage and they are likely to be primarily concerned with situations that negatively impact them in a direct manner. Although import-competing sectors would theoretically be covered by a trade-impacted proposal, it is most likely that the export sectors would bear the brunt of any sanctions. Among traded-goods, Aggarwal (1995) and Morici and Schulz (2001) argue that the greatest problems are in Southern export sectors. This is supported by the fact that a 1988 amendment to Section 301 of U.S. trade law allows the United States to retaliate against foreign nations that restrict U.S. exports due to the failure to respect workers rights; however, given the lack of political will or the difficulty in making such a connection, no Section 301 cases have ever been instituted based on workers' rights violations.

Assuming that only trade-impacted goods are likely to be covered by a tradelabor linkage, which labor rights are likely to have a measurable impact on trading patterns? Although forced labor may be significant for a few small countries (i.e., Burma), enforcement of this provision is unlikely to have any significant impact on North-South trade (especially if only enforced in the tradable sectors). If restrictions on child labor are enforced for only the tradable sectors, then the child 
labor making these products will most likely just move to the nontraded sectors where most child labor is already currently employed; there would be few economy-wide impacts. Thus a trade-labor linkage that included restrictions on forced labor and child labor, that was restricted to the tradable sector, would have only a very minor impact on economy-wide variables with minimal effects on trade patterns. The right to unionize, or the implementation of acceptable working conditions or living wages in the tradable sectors, however, would appear to be labor standards that could result in a change in the pattern of trade. In addition, when violations apply only to the export sector, standards may fall in the nonexport sectors as scarce government enforcement resources concentrate on the export sector. Thus in this paper, instead of trying to address the implications of all of the core labor standards, the focus is restricted to those labor policies that have a realistic probability of being implemented and are likely to have a measurable impact on trade.

The assumption of this analysis is that improved union rights, acceptable working conditions, and living wage campaigns will attempt, at least, to raise nominal wages in the export sector; the reallocative effects of this policy are then analyzed. The economic implications of higher export sector wages depend significantly on what is assumed to be the initial conditions in the Southern labor market. Is there a sectoral distortion to begin with as is often alleged by labor standards supporters, and if so to what degree does it matter what type of distortion it is? If there is no distortion will the labor standard create one? These issues are examined using a basic neoclassical trade model that has been slightly modified and quantified so as to be a miniature computable general equilibrium model. Several scenarios are investigated; first, it is assumed that there is nothing particularly different about the export sector and wages are determined competitively. The introduction of the labor standard then creates a wage differential favoring the export sector. Secondly, it is assumed that wages are initially lower in the export sector, due perhaps to a government policy of promoting export competitiveness. The labor standard then restores wages in the export sector to the competitive level. Thirdly, the export sector is modeled as having a monopsonistic labor market that keeps wages in that sector below the competitive level. The labor standard then either eliminates the monopsony labor market or alters the monopsony outcome with higher wages due to a union or a higher minimum wage. 


\section{A Miniature Computable General Equilibrium Model}

In this section, a miniature computable general equilibrium (CGE) model is developed and various scenarios are run on it that allow the distributional effects of the initial distortion and the labor standard to be quantified. There are a number of papers that deal with the implications of wage differentials and monopsony, however these papers deal almost exclusively with how these distortions alter a free trade outcome where factor-price equalization has occurred. The results of these papers often only specify the qualitative direction of changes and often these changes are dependent on the relative magnitudes of certain variables or elasticities that are difficult to interpret. The CGE approach used here allows a model that is not only more realistic, but is also able to deal with second-best welfare outcomes, and is able to provide quantitative changes so that different scenarios can be compared. Every attempt has been made to present a model with reasonable parameters, however, for those that disagree with the conclusions presented here, a major objective of this paper will have been achieved if those that disagree are forced to specify their own model and parameters.

The model used here has the flavor of the "quick and dirty" CGE approach of Krugman (1995), Kim and Mieszkowski (2001), Pfluger (2001), and to a lesser degree Cline (1997). The model is a consistent general equilibrium model based upon the well-established Heckscher-Ohlin (H-O) trade model but with a number of enhancements to make it more realistic. More specifically, Hicks-neutral technical differences, trade impediments, unequal factor prices, and absorption differences are incorporated into the model. The model has two countries - a capital abundant North $(N)$ and a labor abundant South $(S)$, two goods - capital intensive $(X)$ and labor intensive $(Y)$, and two factors - capital $(K)$ and labor $(L)$. As with Krugman (1995), a Cobb-Douglas functional form is used for the production and utility functions since it simplifies the computations, and most empirical estimates suggest something close to a unitary elasticity. Direct estimation of industry production functions (Balistreri, McDaniel, and Wong, 2001) and the relatively constant share of national income in the United States going to labor and capital strongly suggest aggregate Cobb-Douglas production functions. ${ }^{3}$ In the

\footnotetext{
${ }^{3}$ The Cobb-Douglas production functions do have the undesirable feature that the resulting production possibility frontier is rather linear. Note that Cline (1997) and Kim and Mieszkowski (2001) in examining the growing skilled/unskilled wage differential, have used CES production functions in addition to $\mathrm{CD}$ functions; that specification may be required within that framework since the relative income shares of these worker groups have not remained constant as have the labor-capital shares.
} 
standard H-O model, technology is assumed similar in both countries; there is ample evidence (Trefler, 1995; Davis and Weinstein, 1998) that this is an unrealistic assumption and so a Hicks-neutral technical efficiency parameter $A$ is added to allow the richer nation to have higher total factor productivity. The four production functions have the basic form:

$$
\begin{aligned}
Q_{X N} & =A K_{X N}^{\alpha} L_{X N}^{1-\alpha} \\
Q_{Y N} & =A K_{Y N}^{\beta} L_{Y N}^{1-\beta} \\
Q_{X S} & =K_{X S}^{\alpha} L_{X S}^{1-\alpha} \\
Q_{Y S} & =K_{Y S}^{\beta} L_{Y S}^{1-\beta}
\end{aligned}
$$

where $Q$ represents output in physical units; thus $Q_{X N}$ represents the output of good $X$ in the North. The technical parameter $A$ is greater than one and is assumed similar for both goods produced in the North.

Consumer preferences (and welfare) are also defined with Cobb-Douglas functions (as in Krugman (1995), Cline (1997), and Kim and Mieszkowski (2001)), which are assumed to be identical in the two countries. In addition, individuals within each country are assumed to have identical and homothetic preferences and since all consumers within a nation always face the same prices for any of the outcomes discussed here, the community utility function is also a community welfare function. Where consumption of $\operatorname{good} X$ in the North is labeled $C_{X N}$, the national utility (also referred to as national welfare) functions are given by equations 5 and 6 :

$$
\begin{aligned}
& U_{N}=C_{X N}^{\rho} C_{Y N}^{1-\rho} \\
& U_{S}=C_{X S}^{\rho} C_{Y S}^{1-\rho}
\end{aligned}
$$

Since there are still obvious barriers to trade and this model wishes to analyze the effects of economic policy changes under realistic conditions, both countries are assumed to levy an ad valorem tariff on imports. The tariff of the North is $T_{N}$ and levied on Northern imports of good $Y$, and the tariff of the South is $T_{S}$ and is levied on Southern imports of good $X$. The domestic price of good $Y$ in the South is set as the numéraire, thus $P_{Y S}=1$. Therefore the price of good $Y$ in the North 
equals:

$$
P_{Y N}=1+T_{N}
$$

The price of good $X$ in the North $\left(P_{X N}\right)$ is determined endogenously by the model while the price of good $X$ in the South is:

$$
P_{X S}=P_{X N}\left(1+T_{S}\right)
$$

Given the assumptions outlined in the previous section, and the properties of a market economy that insure the usual marginal conditions needed for profit and utility optimization, it is possible to specify a general equilibrium model of the world economy. Competitive markets require that the marginal revenue product of a factor in each industry must be equal; therefore:

$$
\begin{gathered}
\left(\partial Q_{X N} / \partial K_{X N}\right) P_{X N}=\left(\partial Q_{Y N} / \partial K_{Y N}\right)\left(1+T_{N}\right) \\
\left(\partial Q_{X N} / \partial L_{X N}\right) P_{X N}=\left(\partial Q_{Y N} / \partial L_{Y N}\right)\left(1+T_{N}\right) \\
\left(\partial Q_{X S} / \partial K_{X S}\right)\left(P_{X S}\right)\left(1+T_{S}\right)=\partial Q_{Y S} / \partial K_{Y S} \\
\left(\partial Q_{X S} / \partial L_{X S}\right)\left(P_{X S}\right)\left(1+T_{S}\right)=\partial Q_{Y S} / \partial L_{Y S}
\end{gathered}
$$

The use of each factor in the production of both goods within a country will exhaust the total endowment of each factor in each country. Thus, where $K_{N}$ is the endowment of capital in the North:

$$
\begin{aligned}
K_{X N}+K_{Y N} & =K_{N} \\
L_{X N}+L_{Y N} & =L_{N} \\
K_{X S}+K_{Y S} & =K_{S} \\
L_{X S}+L_{Y S} & =L_{S}
\end{aligned}
$$

Exports (in physical units) of a given country are the difference between domestic production and domestic consumption, thus the export functions are:

$$
\begin{aligned}
E_{X N} & =Q_{X N}-C_{X N} \\
E_{Y S} & =Q_{Y S}-C_{Y S}
\end{aligned}
$$

Total production of each good must equal total consumption of each good. Thus:

$$
\begin{aligned}
& Q_{X N}+Q_{X S}=C_{X N}+C_{X S} \\
& Q_{Y N}+Q_{Y S}=C_{Y N}+C_{Y S}
\end{aligned}
$$

The tariff revenue $(R)$ obtained by each country is given by:

$$
\begin{gathered}
R_{N}=E_{Y S} T_{N} \\
R_{S}=E_{X N} P_{X N} T_{S}
\end{gathered}
$$

National income $(G)$ is equal to the nominal value of output plus tariff revenue; therefore:

$$
\begin{aligned}
& G_{N}=P_{X N} Q_{X N}+\left(1+T_{N}\right) Q_{Y N}+R_{N} \\
& G_{S}=P_{X N}\left(1+T_{S}\right) Q_{X S}+Q_{Y S}+R_{S}
\end{aligned}
$$


From the utility functions and the national income functions, the consumption functions for each good by each country can be derived as:

$$
\begin{gathered}
C_{X N}=\rho G_{N} / P_{X N} \\
C_{Y N}=(1-\rho) G_{N} / P_{Y N} \\
C_{X S}=\rho G_{S} /\left(P_{X N}\left(1+T_{S}\right)\right) \\
C_{Y S}=(1-\rho) G_{S}
\end{gathered}
$$

The above 28 equations specify a miniature core model of the global economy. Due to Walras' law, one of the equations is redundant, and therefore there are only 27 independent equations. This core model has 27 variables $\left(G_{S}, G_{N}, U_{N}, U_{S}, Q_{X N}\right.$, $Q_{Y N}, Q_{X S}, Q_{Y S}, C_{X N}, C_{Y N}, C_{X S}, C_{Y S}, E_{X N}, E_{Y S}, R_{N}, R_{S}, K_{X N}, K_{Y N}, L_{X N}, L_{Y N}, K_{X S}, K_{Y S}$, $\left.L_{X S}, L_{Y S}, P_{X N}, P_{Y N}, P_{X S}\right)$ and 9 exogenous parameters $\left(\alpha, \beta, \rho, A, K_{N}, K_{S}, L_{N}, L_{S}, T_{N}, T_{S}\right)$.

Note that the tariffs and the technical efficiency differences insure that factor price equalization does not occur; wages will always be higher in the North and the $K / L$ ratio for producing both goods will be higher in the North as is consistent with the findings of Dollar, Wolff, and Baumol (1988). Since the objective of the paper is not to provide the most comprehensive model possible but the simplest model possible, the non-traded sector is left out due to the belief that it adds nothing substantive to the questions addressed in this paper.

Another major departure from reality is that all labor is being grouped together; defining both an unskilled labor and a skilled labor would be desirable. This significantly increases the complexity of the model and would make it more difficult to graph the welfare effects using simple graphs. However, Johnson and Mieszkowski (1970) investigated this issue in a paper addressing union induced wage differentials favoring unskilled labor, and concluded generally that the addition of two labor types (in addition to capital) did not significantly alter their conclusions obtained when using only one type of labor and capital.

The wage of labor in the North in industry $X$ (and industry $Y$ as long as there are no distortions) is given by:

$$
W_{X N}=W_{Y N}=(1-\alpha) Q_{X N} P_{X N} / L_{X N}=(1-\beta) Q_{Y N}\left(1+T_{N}\right) / L_{Y N}
$$

Similarly, wages in the South equal:

$$
W_{X S}=W_{Y S}=(1-\alpha) Q_{X S} P_{X S} / L_{X S}=(1-\beta) Q_{Y S} / L_{Y N}
$$

The return to capital in the North in industry $X$ (and industry $Y$ as long as there are no distortions) is given by:

$$
I_{X N}=I_{Y N}=\alpha Q_{X N} P_{X N} / K_{X N}=\beta Q_{Y N}\left(1+T_{N}\right) / K_{Y N}
$$

Similarly, the return to capital in the South equals:

$$
I_{X S}=I_{Y S}=\alpha Q_{X S} P_{X S} / K_{X S}=\beta Q_{Y S} / K_{Y S}
$$


In order to specify the welfare (utility level) of the factors, it is necessary to specify how the tariff revenue is distributed to the factors. It is assumed arbitrarily that two-thirds of the tariff revenue is distributed (lump-sum) to labor and one third to capital; these represent the general share of national income going to each factor. How the tariff revenue is distributed does not affect the results since it is quite small, but it must nevertheless be specified so that the sum of the income to all the factors equals national income. The collective utility level (welfare) of each factor is:

$$
\begin{gathered}
U_{L N}=\left(L_{N} W_{X N}+.667 R_{N}\right) U_{N} / G_{N} \\
U_{K N}=\left(K_{N} I_{X N}+.333 R_{N}\right) U_{N} / G_{N} \\
U_{K S}=\left(K_{S} I_{X S}+.333 R_{S}\right) U_{S} / G_{S} \\
U_{L S}=\left(L_{X S} W_{X S}+L_{Y S} W_{Y S}+.667 R_{S}\right) U_{S} / G_{S}
\end{gathered}
$$

Since in the cases to be analyzed, the wage in sectors $X$ and $Y$ in the South will sometimes differ, $W_{X S}$ need not always equal $W_{Y S}$. Also, since the amount of labor in each sector will also change due to policy changes, it is most useful to derive the utility level for each worker in each sector in the South. The utility for each individual worker in each sector equals:

$$
\begin{aligned}
& U U_{L X S}=\left(W_{X S}+.667 R_{S} / L_{S}\right) U_{S} / G_{S} \\
& U U_{L Y S}=\left(W_{Y S}+.667 R_{S} / L_{S}\right) U_{S} / G_{S}
\end{aligned}
$$

\section{Selecting the Values of the Parameters}

The parameters of the model have been chosen so as to provide the most realistic model possible. Given the simplicity of the model, the lack of aggregate estimates for the parameters, and inconsistencies in data collection, etc., each parameter can not be set solely on its own merits, but must be chosen in a manner that insures that the overall model is as realistic as possible, i.e., trade-offs have to be made in assigning the parameters.

According to the Penn World Tables, capital stock per worker is several times larger in the industrial countries than in the developing or newly industrializing nations; there is a large variance in the capital stock per worker in the developing world. The U.S. had capital per worker of \$35,993 in 1992 (1985 prices), while capital per worker was $\$ 13,697$ in Mexico, \$7,626 in Turkey, and \$3,598 in the Philippines. The capital stock per worker in the North is set to three times that of the South (i.e., $K_{N} / L_{N}=3 K_{S} / L_{S}$ ). The labor endowment of the South is set at 1.5 times that of the North. 
The production function exponent $\alpha$ is set to .4 for the capital intensive good $(X)$, and $\beta$ is set to .25 for the labor intensive good $(Y)$. These parameters result in an equilibrium in the model in which the $K / L$ ratio used in producing good $X$ is approximately twice that of good $Y$; these parameters also result in labor receiving approximately two-thirds of national income in the North. When examining the content of industrial-developing country trade, there is a lot of conflicting evidence about the $K / L$ ratios in exports relative to imports going back to the Leontief paradox. However, Wood (1994, p.105) concludes that for North-South trade, the $K / L$ ratio of exporting industries in the North is on average about 50 percent higher than that of import-competing sectors.

Given these parameters for the exponents of the production functions, it is clear that the output/labor $(G / L)$ ratios between the North and the South would be too similar relative to the empirical evidence. For example, using the Penn World Tables it is the case that the ratio of two countries' output/labor ratios are roughly similar to their capital/labor ratios. In order to achieve this outcome, the richer country must be assumed to have a higher level of technical efficiency. The technical efficiency parameter is set to 2 (i.e., $A=2$ ); given all the other factors and parameters in this model, once an equilibrium is established it will turn out that the $G / L$ ratio of the North is roughly triple (2.8 times) that of the South. Thus the South in this model represents not a poor developing nation but one of the more developed newly industrialized economies.

Note that the above relationships are also consistent with the empirical regularity that the capital to output ratios $(K / G)$ do not differ significantly across all levels of development. For example the capital-output ratios for the U.S., EU, Latin America, and the Asian NICs are 2.7, 3.0, 3.0, and 2.7 respectively (Cline, Table 4.1, 1997). Given the chosen parameters, the $K / G$ ratios for the North and South in the model are similar. The consumption function exponents are set at .5 $(\rho=.5)$ somewhat arbitrarily. For the initial base case scenario, we set $T_{N}=.05$ and $T_{S}=.08 .{ }^{4}$ Having specified reasonable "ballpark" estimates for the parameters, this miniature general equilibrium model generates key variables, which have relative magnitudes similar to those found between the industrialized and the newly developing nations.

Since the focus of the analysis of this paper is on the welfare of the factors of

\footnotetext{
${ }^{4}$ The average trade weighted tariff of OECD countries for items from the developing countries is 4.8 percent; the average trade weighted tariff of developing countries for items from the OECD countries is 10.7 percent (Table 2, page 20, OECD, 1999).
} 
production, their welfares will be primarily measured in terms of utility. Since both the prices of the goods and the incomes of the factors will change, using nominal income levels would be misleading. Since the utility function is homogeneous of degree one, utility changes are equivalent to equivalent variations in income.

\section{Welfare Effects by Factor for Trade Liberalization}

The basic properties of the model described above are outlined in this section. In order to describe the welfare changes of various policies, a basic graphical apparatus will be used. In Figure 1 the welfare (utility level) of Northern capital is placed on the vertical axis and the welfare of Northern labor is placed on the horizontal axis. The levels determined from the basic model with the previously assigned parameters and assuming no wage differentials or no monopsony are referred to as the base levels and are labeled throughout the diagrams as point $B$. Those points up and to the right (down and to the left) of point $B$ are combinations of utility where both capital and labor are better off (worse off); those up and to the left (down and to the right) represent points where capital (labor) is better off while labor (capital) is worse off. A line going through $B$ with a slope of minus one (or 45 degree line), referred to as the isoutility line, gives combinations where total national utility $\left(U_{N}=U_{L N}+U_{K N}\right)$ is constant; those points to the right of a given isoutility line represent higher national welfare and those to the left lower national welfare.

As the tariff level for the North $\left(T_{N}\right)$ is varied, the welfares of the factors are

Figure 1. The Effects of Liberalization on Nothern Welfare

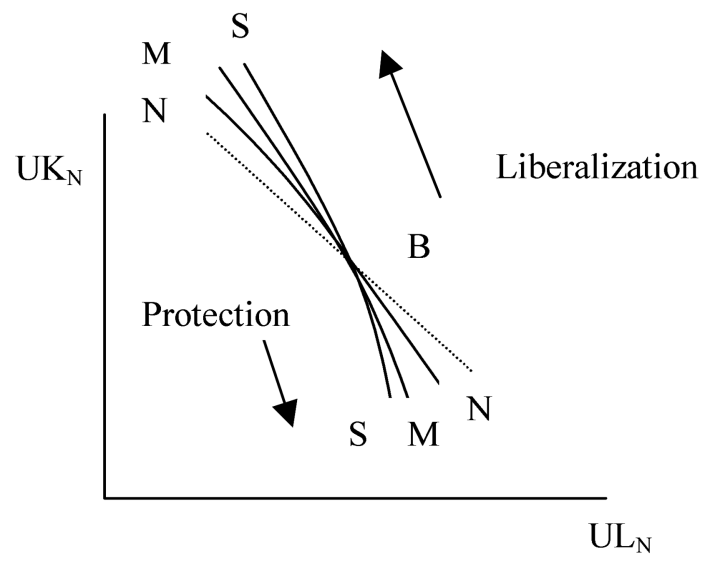


plotted along the line labeled as $N N$. Liberalizations move the welfare point up and to the left, while increases in protection move the welfare point down and to the right. Note three properties of this line: 1) it is negatively sloped, 2) it is steeper than the isoutility line (the 45-degree dotted line), and 3) it is concave to the origin. The line is negatively sloped because the basic model is described by the StolperSamuelson theorem. This seems consistent with the empirical literature surrounding the trade and wages debate. ${ }^{5}$ The line is steeper than the isoutility line because the base tariff is above the optimal tariff rate; thus a unilateral liberalization (i.e., a reduction in $T_{N}$ ) increases overall Northern welfare and an increase in protection reduces overall Northern welfare. The line is concave to the origin because the base tariff rate is close to the optimal tariff rate so that as the level of liberalization increases, the gains get smaller and welfare eventually reaches a maximum after which further liberalization reduces welfare. If a lumpsum transfer is possible which has no dead weight loss, the welfare point can be moved along an isoutility curve. It is in this sense that trade liberalization is generally thought to increase potential welfare since with a transfer both capital and labor could be made better off.

The level of protection in the South $\left(T_{S}\right)$ can also be adjusted, and the resulting effects on the welfares of Northern capital and labor can be plotted. This curve is labeled as $S S$ and is steeper than the $N N$ curve. Southern liberalization creates a greater net welfare increase (relative to amount of income redistribution) in the North compared to a Northern unilateral liberalization since it not only increases trade (as does a Northern liberalization) but also improves the terms of trade $\left(T O T_{N}\right)$ of the North. Also plotted in Figure 1 is a curve representing a mutual liberalization or tariff increase of the same amount (i.e., $\Delta T_{S}=\Delta T_{N}$ ) and is labeled $M M$. The $M M$ curve lies between the $N N$ and the $S S$ curves.

The utilities of Southern capital and labor have a similar set of curves which are presented in Figure 2, but they differ from the North's curves in several important aspects. Since the South is labor abundant, a domestic or foreign liberalization improves labor's welfare and overall welfare, while increased protection improves capital's welfare while lowering overall welfare. As with the North, a foreign liberalization $(N N)$ produces less of a welfare trade-off between the factors than does a domestic liberalization (SS).

\footnotetext{
${ }^{5}$ If there are additional "dynamic" gains from trade, in addition to those of specialization and exchange as developed here, a more positive sloped welfare line results so that it might be possible that both labor and capital could gain from trade liberalization.
} 
Figure 2. The Effects of Liberalization on Southern Welfare

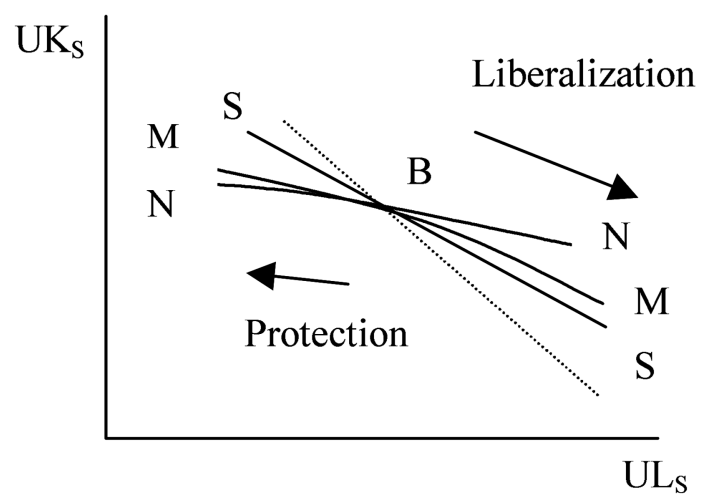

\section{Introduction of Labor Standards in the Export Sector}

As previously discussed, the living wage campaigns and/or implementing union rights into trade agreements are likely to increase wages in the South's export sector relative to that in the remaining sectors. There are several ways increased unionization and living wages could be modeled; for several reasons it is believed that the most appropriate way to model this is simply as a policy that either creates a new wage differential favoring the export sector or eliminates an existing differential harming workers in the export sector. The wage differential approach is chosen because 1) living wages actually attempt to create a wage differential, 2) changing Southern minimum wages is likely to result in either the elimination or creation of a differential, 3) a union's primary effect is to create a wage differential, 4) a wage differential has been the way unions have historically been modeled in the international trade literature, 5) higher standards in the export sector could possibly lower standards in the other sectors by reallocating enforcement efforts, and 6) there is a large existing body of economic literature analyzing how wage differentials impact trade.

Although the living wage campaigns advocate increasing wages to a level that would supposedly allow workers to achieve some absolute level of "basic needs," the evidence tends to show that these wage levels are not actually based upon some absolute standard but are being determined as a premium relative to some "equilibrium wage" for unskilled labor in that country (U.S. Labor Dept., 2000; Fisher, 1995). It is sometimes alleged that governments set minimum wages in a manner that keeps wages lower in the export sectors. It is often difficult to 
evaluate minimum wages in many developing countries which lack a certain degree of homogeneity in economic development since minimum wages are often set on a regional basis (i.e., Indonesia, Mexico, the Philippines) or on an occupational basis (i.e., Mexico, India, Pakistan; Costa Rica has 72 different minimum wages (ILO, 2000b)). Given all these different rates, it is difficult to determine if there is a bias for or against export production. If there is some bias for or against workers in the export sector achieved through manipulating minimum wages, it is easiest to model this as a wage differential. The wage differential approach is also consistent with the hypothesis that labor enforcement resources are limited and where enforcement is increased in the export sector it is likely to be reduced in the other sectors.

A significant aspect of improving labor standards is increasing the ability of workers to form unions and negotiate wage increases. A union is assumed, as is standard in general equilibrium trade theory and supported by a large body of empirical evidence, to obtain an exogenous wage differential (Johnson and Mieszkowski, 1970). Labor economists have often concluded that unions negotiate not only for wages but also for the employment level as well. If this is the case, the bargained outcome need not be a point on the marginal product of labor curve. If there is to be some trade-off between higher wages and employment, exactly how this trade-off will be made depends on a number of factors such as whether lay-offs are seniority based or random (Grossman-1984). It remains to be demonstrated whether modeling the wage distortion as an endogenous outcome from optimizing union behavior would significantly alter the results. The wage differential approach is therefore a more general modeling assumption that is able to incorporate a number of different possibilities (i.e., sectoral or occupational minimum wages, "voluntary" living wages, differential enforcement, or selective unionization rights) that might result from higher (or increased) labor rights in the export sector.

A standard that creates a wage differential: Beginning with the case where there is no initial differential, it is assumed that improving labor standards in the South's export sector creates a wage differential of $D_{S}$ favoring workers in sector $Y$ such that $W_{Y S} / W_{X S}=1+D_{S}$, where $D_{S}>0$. As a result, the equilibrium conditions specified in equation (12) for the base case will no longer hold and will be replaced by the following:

$$
\left(\partial Q_{X S} / \partial L_{X S}\right)\left(P_{X S}\right)\left(1+T_{S}\right)\left(1+D_{S}\right)=\partial Q_{Y S} \partial L_{Y S}
$$

All the other equations of the model remain the same. 
It has been suggested by Maskus (1997) that the creation of a wage differential could also create unemployment of a Harris-Todaro (1970) type whereby individuals choose to remain unemployed in order to wait for the higher paying jobs. ${ }^{6}$ This may be a realistic possibility for the urban-rural wage differential that Harris-Todaro examine, since in a developing country it is difficult to get an urban job while living and working in a rural area. However, for the traded/non-traded sector wage differential discussed here, the Harris-Todaro hypothesis is less realistic since there would appear to be no reason that a worker could not work in the nontraded sector while in the queue for a higher wage job in the export sector. ${ }^{7}$ However, when the export goods are produced in different geographical locations than the non-export goods, as with some export processing zones and possibly the maquila industries in Mexico, the Harris-Todaro hypothesis may be more relevant. The model developed here, however, does not allow the wage differential to increase aggregate unemployment.

What are the economic effects of creating a wage differential? Since the relative costs of producing good $Y$ will increase in the South, the South's comparative advantage in producing $Y$ will fall. ${ }^{8}$ As such, the volume of trade will fall and since good $Y$ becomes relatively scarcer globally, its relative price will increase (i.e., the South's terms of trade must improve). Since the two regions are less able to benefit from specialization and trade, overall welfare in each region will fall (given the parameters, the volume effect outweighs the TOT effect for the South). In the South, the labor standard improves the welfare of capital while the welfare of labor (collectively) falls. This result is consistent with the well-established results of $\mathrm{H}-\mathrm{O}$ trade theory that an increase in a factor distortion benefiting the

\footnotetext{
${ }^{6}$ The actual Harris-Todaro model includes a number of other differences from the basic $\mathrm{H}-\mathrm{O}$ trade model such as sector specific capital. The Corden-Findlay (1975) model incorporates the Harris-Todaro labor market into the basic H-O framework.

${ }^{7}$ It is possible, as modeled by Fields and Grinols (1991) that those without work would have a higher probability of finding work since they have more time to devote to the search. However, it may also be the case that those currently with jobs could be viewed by employers as "better" workers and thus be more likely to be hired.
}

\footnotetext{
${ }^{8}$ The existence of factor market differentials can reverse relative factor intensities and result in a difference between physical and value measures of factor intensity. The output response to factor price differentials and goods prices is normal only if physical and value factor intensities are similar. Value reversal is ruled out by the use of Cobb-Douglas production functions, and the analysis here is restricted to differentials that are not large enough to create a physical factor intensity reversal (Magee, 1973). Note that a physical factor intensity reversal would also result in a convex production possibilities curve (Johnson, 1966).
} 
abundant factor in the industry that intensively uses that factor lowers the welfare of that factor (Batra and Pattanaik, 1971; and Magee, 1973). This is shown in Figure 3 where those points up and to the left of point $B$ represent the situation where the labor standard increases the wage in the Southern export sector relative to the import sector $\left(W_{Y S}>W_{X S}\right)$. Perhaps what is more surprising is that the labor standard not only lowers the welfare of labor overall, but even lowers the welfare of labor in the sector obtaining the differential $\left(\Delta U U_{L X S}<\Delta U U_{L Y S}<0\right) .{ }^{9}$ This is shown in Figure 4 as points to the right of point $B$.

In the North, a Southern wage differential increases labor's welfare and lowers capital's welfare. This is shown in Figure 5 along the curve down and to the right of point $B$. The Southern wage differential causes Northern welfare to fall overall. Given the parameters of the model, it turns out that this labor standards curve has

Figure 3. A Southern Wage Differential's Effects on Southern Welfare

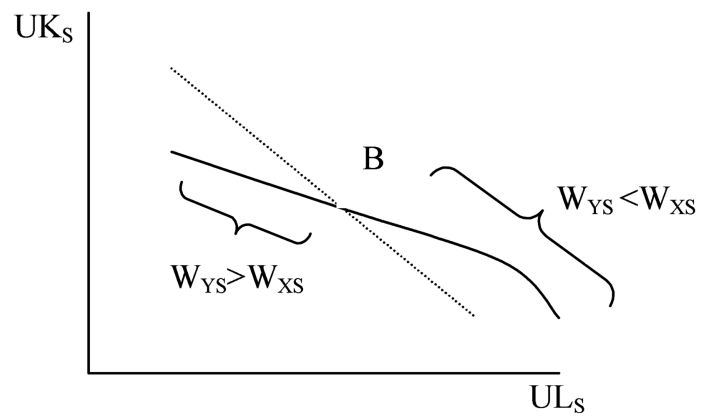

Figure 4. A Southern Wage Differential's Effects on Southern Workers' Welfare by Sector

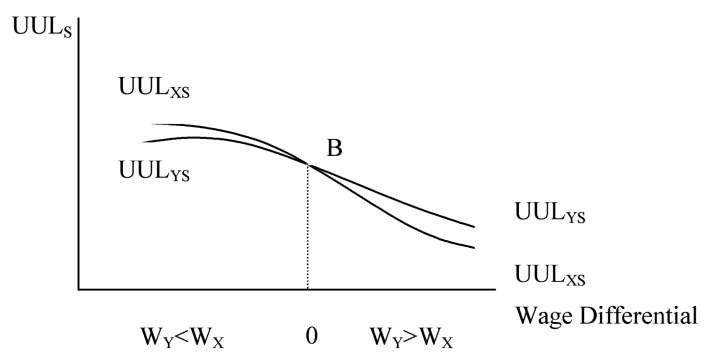

\footnotetext{
${ }^{9}$ It is possible for labor in the export sector to gain (although labor overall will lose) if the parameters of the model are chosen so as to make the demand for the South's export good Y sufficiently inelastic (Jones, 1971). However, since a higher relative price for good $Y$ also increases the output of $Y$ in the North, even an inelastic demand for good $\mathrm{Y}$ overall does not necessarily imply an inelastic demand for good Y from the South. The Cobb-Douglas utility function assumed here obviously assumes a unitary demand for $\mathrm{Y}$ in each country.
} 
roughly a similar slope as the $S S$ curve in Figure 1. Thus as a method to increase Northern worker's welfare, a foreign labor standard that creates an export sector wage differential imposes a greater efficiency loss than does increasing Northern tariffs since in Figure 1 the $N N$ curve is flatter than the SS curve which has a slope similar to the wage differential curve in Figure 5. Thus from the North's perspective, increasing a domestic tariff is superior to imposing a foreign labor standard as a way to improve Northern labor's welfare.

In summary, if the effect of the increased standard is to raise wages in the South's export sector relative to its import sector, the result is a lowering of welfare for all the workers in the South, especially those not in the export sector. Although Southern welfare falls overall, the welfare of the capitalists improves. This result therefore suggests that Southern workers should justifiably be skeptical of the labor standards movement. However, Northern workers gain and Northern capitalists lose, so their positions on the labor standards issue are consistent with these predicted economic effects.

A standard that eliminates an existing differential: Some supporters of labor standards argue that the initial condition is not one of equality (i.e., no wage differential) but one where the government has restricted worker's rights "more" in the export sector so as to achieve a competitive advantage in exporting. This could be achieved by setting regional or sectoral minimum wages, or setting or enforcing labor rights in a manner so as to bias production in favor of exports. Thus improved standards would not create a new differential but are needed to eliminate an existing differential. Although one's initial reaction might be that the elimination of an existing differentiation is different from the creation of a new differential (due to closed economy Pareto optimality conditions), it turns out that

Figure 5. A Southern Wage Differential's and Monopsony's Effects on Nothern Welfare

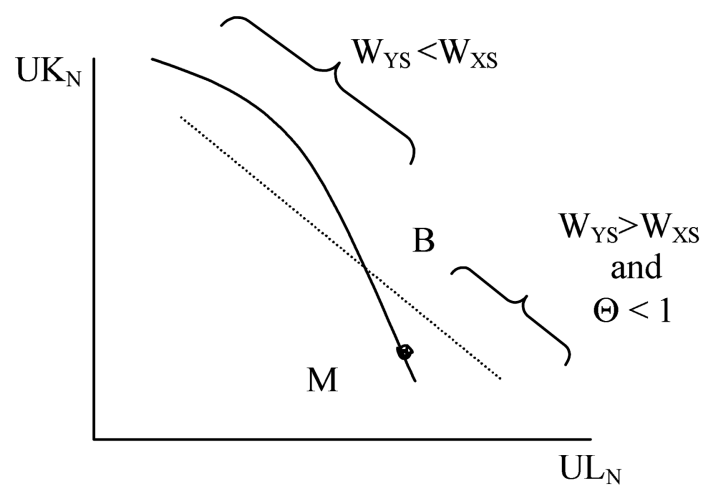


the substantive differences between the two cases are surprisingly small.

A developing country government has some "bargaining power" relative to international capital for production for the domestic market. In order to get behind domestic tariff barriers, the firm has little choice but to pay domestic labor a government mandated wage. However, for production that is to be exported back to a developed country, the developing country has no real bargaining power and must compete with other developing countries to make things attractive for foreign capital. ${ }^{10}$ Additional reasons for keeping wages lower in the export sector include the usual arguments for export subsidies capturing oligopolistic rents, increasing returns, reducing unemployment, or improving the TOT. ${ }^{11}$

There is some empirical evidence that developing countries do indeed have lower minimum wages and restricted labor rights to unionize in export industries and especially in export processing zones. For example, legal labor rights are more limited in export processing zones relative to the rest of the economy in Pakistan, Bangladesh, Ecuador, Seychelles, Namibia, and Malaysia (electronics sector). In Mauritius the minimum wage for unskilled labor in the export processing zones is less than 50 percent of the minimum wage for unskilled workers in the rest of the economy (ILO, 2000). ${ }^{12}$ Despite these examples, it is more generally found that wages in export processing zones are higher than those outside the zones (ILO, 1998); however, it may be the exceptional cases that are the focus of the supporters of improved labor standards. Even in the cases where wages are higher in EPZs, this result does not necessarily mean that workers in the export sector are not being "exploited more" than in other sectors since workers in the export sectors are likely to be more skilled than unskilled labor generally and these workers may be required to work harder; thus this comparison of average wages

\footnotetext{
${ }^{10}$ When a country lowers labor standards throughout the economy, that lowers labor costs, but since every firm gets lower costs, that lowers prices so profitability doesn't increase much. Thus this policy may not attract much foreign capital. However, when labor standards are lowered only in export processing zones (EPZs), this lowers wage costs but is unlikely to lower the prices for internationally traded goods, thus profitability increases and this is likely to attract foreign capital. Thus foreign capital is likely to be much more responsive to lower labor standards in export processing zones than to lower economy-wide standards. As such, a country, if it is interested in attracting foreign capital, has more incentive to lower labor standards in EPZs than economy-wide.

${ }^{11}$ Itoh and Kiyono (1987) show that when there are more than two goods, an export subsidy can improve the TOT.

${ }^{12}$ Note that while labor standards supporters are critical of this type of labor policy, Rodrik (2001) cites the EPZ model of Mauritius as an example of an effective and desirable development strategy.
} 
in the two sectors may fail to properly account for minor skill differences or required work effort. In some sense, workers in EPZs may be obtaining higher wages as "compensation" for having lower rights (such as forced overtime or reduced protections against sexual harassment). It is possible that improved worker rights would then result in lower wages. However, in the developed nations it does not appear that the effect of unions is to lower wages (relative to other workers) as compensation for increasing other labor rights. Thus it is assumed that union rights improve wages and working conditions instead of trading one for the other.

The issue of whether lower labor rights in EPZs constitute an unfair subsidy or unfair trading practice has never been raised formally, such as at the WTO; however, some have suggested this should be pursued, and the 1988 Omnibus Trade and Competitiveness Act requested that the U.S. Labor Department investigate the implications of differential labor rights in EPZs.

The case where there is initially a wage differential that keeps wages lower in the export sector (henceforth referred to as a negative wage differential) can be modeled in a manner similar to the wage differential case already examined except that in the initial equilibrium the labor market in the South is given by equation (12)* where $-1<D_{S}<0$. Thus $W_{Y S} / W_{X S}=1+D_{S}<1$. The effects of a negative wage differential on Southern welfare are also plotted in Figures 3 and 4 as the sections of those curves where $W_{Y S}<W_{X S}$. As is plotted in Figure 3, a differential lowering wages in the export sector increases Southern welfare, up to a point. How is it possible that a negative wage differential can increase welfare (relative to no differential) given the so-called Pareto optimality conditions, which are generally thought to require no factor price differentials? Pareto optimality assumes that the marginal rate of domestic transformation through trade equals the marginal rate of transformation through production; however, in order for a large country to achieve Pareto optimality it must impose an optimal tariff, and therefore any other tariff rate or even free trade represents a distortion in the goods market. Therefore due to the theory of second best, it is possible for the distortion in the factor markets to partially compensate for the distortion in the goods markets. In the model here, parameters were chosen (because they were assumed reasonable) so that a unilateral tariff reduction by the South increases the South's welfare, and thus the initial tariff was assumed to be above the optimal tariff. Therefore, the South underspecializes in the export good due to the tariff; the existing wage differential, which keeps wages low in the export sector, partially compensates for the tariff distortion and moves the output mix closer to the optimal level of 
specialization. Thus any attempt to eliminate an existing Southern negative wage differential is likely to lower Southern welfare; the exception would be if the South currently had the optimal tariff.

In this model the South is assumed to be a large country, but if the Southern country were a small country then the optimal tariff would be zero. Most small Southern countries have positive tariffs so it seems reasonable that their tariff rates are above their optimal. In this case elimination of the wage differential would have a similar effect as in the model here, i.e., welfare in the country would fall.

The effects of a negative wage differential on wages in the two Southern sectors are plotted in Figure 4. Points to the left of point B represent cases where there is a negative wage differential; the differential increases wages for workers in both sectors. As can be seen, any attempt to raise the wages of export sector workers relative to import workers lowers labor's real income in both sectors regardless of whether the wage in the export sector is initially above, equal to, or below that in the rest of the economy. Thus in terms of labor's welfare, it makes little difference if export workers initially get paid less than other workers (a negative differential) or if they initially get paid the same, or more; in all cases, a labor standard that raises the nominal wage in the export sector ends up lowering the real wage of workers in both the import and export sectors. It is therefore clear that a labor standard that attempts to raise the nominal wages of export workers (assuming otherwise competitive factor markets) only ends up harming them.

It is perhaps worth noting that the situation is entirely different if a wage differential is created favoring labor in a capital-intensive export sector. In the industrialized countries, labor was generally first unionized and still obtains a wage premium in the capital-intensive export sectors. The effect of this type of wage differential is to definitely increase the real wage in the sector obtaining the differential, and possibly increase the wage of the remaining workers as well (Johnson and Mieszkowski, 1970). Therefore labor activists that have concluded that historically the labor movement had a positive impact on labor in the industrialized countries after unions were created in the export sectors, and based upon that experience have promoted labor movements in the developing nations, have made a serious error in assuming the two cases are similar when, in fact, the implications are not only not similar but polar opposites.

The existence of a negative Southern wage differential increases welfare in the North. This is shown in Figure 5 as points up and to the left of point $B$. This is due to the fact that the differential increases not only the volume of trade but the 
North's TOT. The improved Northern TOT also means that the welfare of Northern capital increases and Northern labor decreases due to StolperSamuelson. It is therefore understandable why Northern labor would wish to eliminate a Southern negative wage differential. Note that the Northern welfare curve resulting from a Southern wage differential has a slope roughly similar to the $S S$ curve in Figure 1. Thus a Southern negative wage differential provides the North a more effective welfare gain than does a unilateral tariff reduction by the North. Also note, that since a unilateral tariff increase by the North will move the welfare point along a flatter curve than eliminating a Southern negative wage differential, the North can achieve a distributional objective of improving its labor's welfare more effectively by increasing tariffs than by eliminating an existing Southern wage differential.

Increasing the relative wage of Southern export sector workers (i.e., increasing $D_{S}$ regardless of the initial sign of $D_{S}$ ) has the effect of increasing the welfare of Northern workers. In fact, raising the wages of Southern export workers results in general equilibrium welfare effects for all the factors that are quite similar to increasing Northern tariffs. In both cases (a higher $D_{S}$ or a higher $T_{N}$ ) there is a decline in the welfare of the North and the South, a decline in the welfare of labor in the South and capital in the North, and an increase in the welfare of capital in the South and labor in the North. It has been suggested by some that introducing labor standards would result in increased protectionism in the North as the North imposed sanctions for the lack of standards; what is less appreciated is how similar labor standards (covering only the export sector), themselves, are to tariffs, not even considering any sanctions.

\section{Monopsonistic Labor Market}

Supporters of international labor standards often argue that wages in the export sector are kept low because of monopsonistic conditions in that labor market (for example, Lee, 2001; Morici and Schulz, 2001; Swinnerton, 1997). The basis of this monopsony power, and why it is more likely in the export sectors has never been formally explained. If the export sectors were concentrated in a geographical area as with some export processing zones or in the Maquila sector along the Mexican-U.S. border, there could be locational adjustment costs that might result in workers willing to settle for a lower wage in the export sector. Alternatively, it is theoretically possible that a minimum wage is set for the non-tradable sectors 
and the excess workers must find employment in the export sector, which is not covered. Due to leisure-work tradeoffs, there could be an upward sloping labor supply curve for this sector. However, it is less clear as to why a given export firm would perceive itself to face an upward sloping supply curve. In the theoretical literature, the existence of monopsony power in factor markets is generally assumed to be due to monopoly power in the output market (Feenstra, 1980; and McCulloch and Yellen, 1980), although theoretically it may be possible to have monopsony factor markets and a competitive output market. In summary, advocates of labor standards raise the monopsonistic possibility although no one has provided a substantive explanation as to why that labor market structure would exist in Southern export markets. One suspects that monopsonistic labor markets are suggested not because of overwhelming evidence of their existence, but because it is well known that a monopsonistic labor market results in Piguovian exploitation which not only results in wages below their "competitive level" but also results in economic inefficiency; the existence of a monopsonistic labor market therefore allows for the possibility that unionization or some other form of intervention might be distributionally attractive while also enhancing allocative efficiency. The fact that wages in the export sectors are generally found to be above the national average wage also seems inconsistent with the monopsony argument.

In order to model monopsony in the labor market of industry $Y$ in the South, it is assumed that industry $\mathrm{Y}$ has a supply curve of labor which allows it to obtain the first worker at a wage of $\theta W_{X S}$ where $\theta<1$. As employment in industry $Y$ approaches the total labor endowment $\left(L_{S}\right)$ the wage in sector $Y$ increases to the wage in sector $X\left(W_{X S}\right)$. Thus the industry faces an upward sloping supply curve that is hinged to the equilibrium wage in the other sector, thus:

$$
W_{Y S}=W_{X S}\left(\theta+(1-\theta) L_{Y S} / L_{S}\right)
$$

The employment level in industry $Y$ is set at the level where the marginal factor cost of labor $\left(M F C L_{Y S}\right)$ equals the marginal revenue product of labor in industry $Y$. Since the total factor cost of labor in industry $Y$ is equal to $W_{Y S} L_{Y S}$, the marginal factor cost is equal to:

$$
M F C L_{Y S}=\partial\left(W_{Y S} L_{Y S}\right) / \partial L_{Y S}=\left(\partial W_{Y S} \partial L_{Y S}\right) L_{Y S}+W_{Y S}
$$

By substituting in the value of $W_{X S}$ for $W_{Y S}$ using equation (39) above, and then taking the derivatives and setting this equal to the marginal revenue product, the equilibrium level of labor used in industry $Y$ is obtained when:

$$
\partial Q_{Y S} / \partial L_{Y S}=W_{X S}(1-\theta) L_{Y S} / L_{S}+W_{X S}\left(\theta+(1-\theta) L_{Y S} / L_{S}\right)
$$


Since the wage in industry $X$ equals the marginal revenue product of labor in industry $X$, (i.e., $\left.W_{X S}=\left(\partial Q_{X S} \partial L_{X S}\right)\left(P_{X N}\right)\left(1+T_{S}\right)\right)$, substituting this expression for $W_{X S}$ gives:

$$
\left.\left(\partial Q_{Y S} / \partial L_{Y S}\right) /\left((1-\theta)\left(2 L_{Y S} / L_{S}\right)+\theta\right)\right)=\left(\partial Q_{X S} / \partial L_{X S}\right)\left(P_{X N}\right)\left(1+T_{S}\right)
$$

Thus equation (42) above replaces equation (12) as the equilibrium condition in the labor market in the South; the other equations (1-11 and 13-28) remain valid and together allow the model to be solved. Figure 6 diagrams the equilibrium conditions that hold in the South's labor market. The horizontal axis represents the total endowment of labor $\left(L_{S}\right)$ and how it is divided between industry $X$ and $Y$. The vertical axis represents the value of wages, marginal revenue products, and the marginal factor cost of labor in industry $Y$. Note that the lines in the graph simply describe the final equilibrium condition; all of the curves are functions of endogenous variables and any change in $L_{Y S}$ not only moves one along the curves but could shift them as well. With prices fixed, if both sectors had competitive labor markets, the South's endowment of labor would be allocated to the two sectors where the marginal revenue products are equal, which occurs at point $L^{C}$ with $L_{X S}=O L^{C}$ and $L_{Y S}=L^{C} L_{S}$. In the monopsonistic case, labor is allocated between the two sectors at point $L^{*}$ with $L_{X S}=O L^{*}$ and $L_{Y S}=L^{*} L_{S}$.

Since the workers get paid different wages in the two industries, a welfare measure for each unit (or worker) of input can be calculated as in equations (37) and (38): where $R_{S}, U_{S}$, and $G_{S}$ continue to be defined by equations (22), (6), and (24) respectively. Note that capital is still allocated so as to equate the marginal revenue products $\left(I_{X S}=I_{Y S}\right)$ in the two industries as in equation (11). However, the capitalists in industry $Y$ now earn, in addition to the marginal revenue of capital,

Figure 6. Southern Labor Market with Monopsony in Sector Y

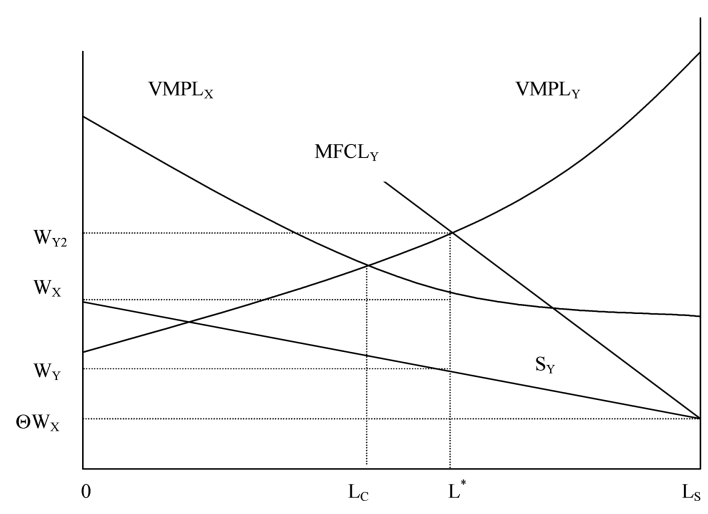


the Piguovian "rent" $(P R)$ of:

$$
P R=\left(\left(\partial Q_{Y S} / \partial L_{Y S}\right)-W_{Y S}\right) L_{Y S}
$$

Thus the utility level for each unit of capital in each industry is given by:

$$
\begin{gathered}
U U_{K X S}=\left(I_{X S}+.33 R_{S} / K_{S}\right) U_{S} / G_{S} \\
U U_{K Y S}=\left(I_{X S}+\left(\left(\partial Q_{Y S} / \partial L_{Y S}\right)-W_{Y S}\right) L_{Y S} / K_{Y S}+.33 R_{S} / K_{S}\right) U_{S} / G_{S}
\end{gathered}
$$

With these functions, it is possible to derive how the welfares of the input factors are affected by the existence of a monopsony labor market in sector $Y$. When $\theta$ is set to one, there is no monopsony and the input factors receive income as they would in fully competitive labor markets. As the value of $\theta$ is decreased, the degree of monopsony power increases in the sense that the labor supply curve of sector $Y$ becomes steeper, and the difference between the marginal factor cost and the supply curve increases.

When $\theta<1$, the Southern wages in both sectors are lower than they would be in a competitive factor market equilibrium. Thus the monopsony not only harms the workers in its sector, but by producing a "surplus" of workers in the other sector, lowers wages in that sector as well. The effects of a monopsony are shown in Figures 7 and 8; point $B$ represents the base case (which includes tariffs) where there is no monopsony. The greater the monopsony power (i.e., the smaller $\theta$ ) the lower the welfare of workers in both sectors and the greater their difference (Figure 7). The effects of monopsony on the welfares of Southern capital and labor are shown in Figure 8; as the level of monopsony increases the welfare point moves from point $B$ towards point $M$. Although capital gains, overall Southern welfare is lower.

Note that the production and factor allocation in the South that results from the monopsony situation shown in Figure 6 would be identical to the production and factor allocation that would result from a positive wage differential of $W_{Y 2} / W_{X}$. All

Figure 7. Monopsony's Effect on Southern Labor's Welfare by Sector

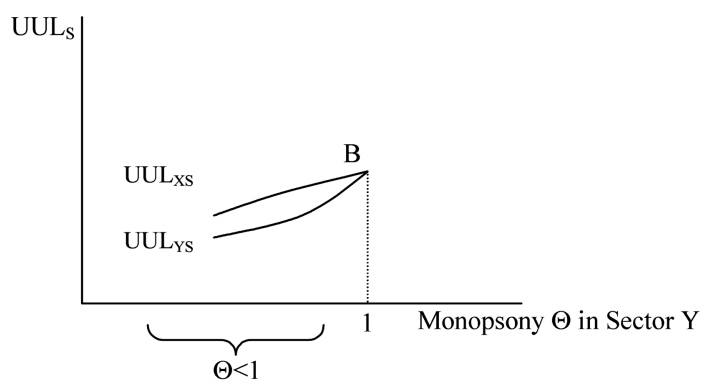


Figure 8. Southern Monopsony's Effect on Southern Welfare

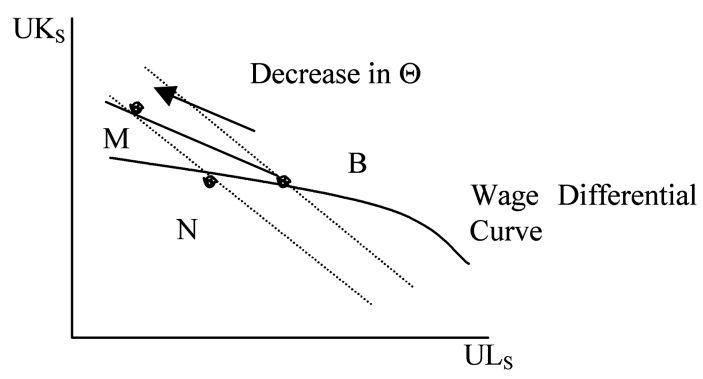

of the variables in general equilibrium would be identical except that the workers in industry $Y$ would obtain the rent instead of the capitalists in industry $Y$. Thus the production, consumption, and trade pattern produced by the monopsony in industry $Y$ given by point $M$ in Figure 8 is identical to the production, consumption, and trade pattern at point $N$ on the wage differential curve. The only difference is that with a wage differential the rent has in effect been transferred lump sum from the capitalists to the workers in sector $Y$. Since point $N$ in Figure 8 corresponds to point $M$ in Figure 5, and since production and trade patterns at points $M$ and $N$ in Figure 8 are identical, it should be clear that the monopsony situation given by point $M$ in Figure 8 results in a welfare situation in the North given by point $M$ in Figure 5 . Thus the solid curve in Figure 5 below and to the right of point $B$ also provides the effects on Northern welfare of a monopsony in industry $Y$ in the South. From the North's perspective, a monopsony in industry $Y$ in the South has the same effect as some equivalent Southern positive wage differential.

With a Southern monopsony in industry $Y$, relative to the base case, the volume of trade is smaller and the North's TOT is lower. Both of these factors cause Northern welfare to fall. The fall in the TOT of the North is due to the fact that the global supply of good $Y$ falls due to the reduced output in the South; therefore the price of good $Y$ increases. Since the price of good $Y$ increases, the output of good $Y$ increases in the North, as does the wage of Northern workers due to StolperSamuelson. Thus the Southern monopsony does not harm Northern labor as is often alleged, but actually increases Northern workers welfare. Likewise, Northern capital is harmed by a Southern monopsony in good $Y$.

If the export sector in the South is characterized by monopsony, depending on what caused the monopsony, it may not be possible for the government to simply eliminate the monopsony; the government's only option (assuming it did not 
create the monopsony to begin with) may be to allow a union or to set a minimum wage. If the union sets a wage or the government establishes a minimum wage the resulting outcome is described by the wage differential curves as long as employment in sector $Y$ is not supply constrained (assuming sector $Y$ still faces the $S_{Y}$ supply curve). If this wage is set to equate wages in the two industries, the competitive outcome results. It is more likely that a union would desire to keep employment fixed (so that no members would lose jobs) and raise wages up to its marginal product, which is $W_{Y 2}$. In such a case, what develops is essentially a bilateral monopoly situation where capital and labor fight over the available rent. There is generally no economic solution as to how this rent will ultimately be divided between the two parties. Assuming that labor is able to obtain all the rent by setting the wage to $W_{Y 2}$, factor usage, output, trade flows, and the level of efficiency will not change. The welfare point in Figure 8 would move southeast along the isoutility curve from point $M$ to point $N$ on the Southern wage differential curve. In this particular and very specific case, the introduction of the union has few implications other than to increase the wage of Southern workers in industry $Y$ (and reduce the income of capital in industry $Y$ in the South). Neither labor nor capital in the North, nor labor in industry $X$ in the South, would be impacted. In this case it would be possible for labor in the South to benefit from a higher labor standard without affecting anything in the North and without harming labor in the non-covered sector $X$ in the South.

If the wage in sector $Y$ is set sufficiently high so that the wage differential is greater than $W_{Y 2} / W_{X}$, Northern labor is better off than in the initial monopsony situation while Southern labor may end up better off (for differentials moderately above $W_{Y 2} / W_{X}$ ) or worse off (for differentials significantly above $W_{Y 2} / W_{X}$ ). Thus with an initial Southern monopsony, it is possible (but not definite) that a higher labor standard could increase labors welfare in both the North and the South. It is also possible that both labor and capital in the South could end up worse off if the union or minimum wage is set too high. Assuming, however, that the union would pick a wage so that employment would not fall (i.e., a wage differential less than $W_{Y 2} / W_{X}$ ), then the Southern welfare point would be on the wage differential curve to the right of point $N$ in Figure 8; the basic effect of the union would be to increase the welfare of Southern labor and lower that of Southern capital. Under these assumptions, the Southern union would also lower the welfare of Northern labor and increase the welfare of Northern capital.

Also note that in the situation where Northern labor gains from the elimination 
of the Southern monopsonist, overall Northern welfare is lower since the outcome is further down (past point $M$ ) on the curve in Figure 5. This conclusion along with that from the wage differential discussion demonstrates that any type of labor standard, be it the creation of a wage differential, elimination of an existing differential, or elimination of a monopsony, harms either Northern welfare or Northern wages. There is no situation where Northern labor $\left(U_{L N}\right)$ and Northern welfare $\left(U_{N}\right)$ can both gain from a higher labor standard in the South. In fact the wage differential curve in Figure 5 is steeper than the increased protectionism curve $(N N)$ in Figure 1. Thus if the intent of the labor standard is to improve Northern labor's welfare, it is an inefficient policy in that for a given level of capital welfare, labor welfare is higher with a higher Northern tariff than with a higher Southern labor standard.

\section{Conclusions}

This paper examines the likely implications of implementing a trade-labor linkage. The only linkage that is politically likely is one that is restricted to tradeimpacted goods, and this is likely to be applied mostly to the export sectors. If higher standards are applied to only the export sectors, restrictions on child labor, forced labor, and perhaps discrimination are likely to only reallocate resources within an economy and they may not have significant economy-wide or trade implications. Enforcement of the right to unionize combined with living wage campaigns, however, may alter a wage differential between the export sector and the rest of the economy. The implications of this are examined in this paper. The results presented here suggest that the economic implications, and thus possible policy implications, are considerably different depending on the source of a Southern wage differential between the import and export sectors. If the initial differential has wages lower in the export sector due to lower minimum wages or restricted union rights, it is possible (and definitely the case within the model and parameters developed here) that a policy to eliminate the differential would actually lower Southern real wages in both sectors. Overall Southern welfare could be harmed as well since the original differential is able to compensate for distortions that normally exist in the final goods market. In this situation, Northern workers gain since the South's comparative advantage is reduced and this reduces the volume of trade; Northern wages increase through Stolper-Samuelson effects 
although Northern welfare falls.

A different situation occurs if the reason for the initially lower wages in the export sector is due to a monopsonistic labor market in that sector. Policies to raise wages in the export sector such as a higher minimum wage or more favorable union rights have the effect (up to a point) of increasing the real wage in both the Southern export and import sectors. In this case, Northern workers are usually harmed (but not always) by the increased labor standard since the output of Southern exports expands and lowers Northern wages through Stolper-Samuelson effects.

There is a possibility that imposing labor standards could create a wage differential (where none existed initially) by increasing nominal wages in the export sector above those in the remainder of the economy. The effect of this outcome would be to lower real wages for all Southern workers and lower the overall welfare of Southern nations - the exact opposite of what labor standards supporters propose. Northern labor's welfare increases although overall Northern welfare falls.

In conclusion, the desirability and economic consequences of higher Southern labor standards, and who gains and loses, depends critically on the nature of Southern labor markets. There are no cases in which Northern labor can gain from higher Southern labor standards without reducing overall Northern welfare. Currently the case for higher Southern labor standards has been made based upon ideological arguments by lawyers and human rights activists. ${ }^{13}$ These participants largely ignore the general equilibrium economic effects of their policy recommendations. These general equilibrium effects need to be analyzed carefully, but as explained here, this can only be done after there has been a careful empirical analysis of the structure of Southern labor markets. Currently, there would appear to be sufficient questions about the desirability of imposing higher Southern labor standards (even ignoring the effect of possible trade sanctions) to suggest that the world community should move cautiously in regards to this issue.

\footnotetext{
${ }^{13}$ In many ways the trade-labor standards movement is similar to the supply-side movement of the 1980s. Both lack a rigorous theoretical foundation and found their way into government policy based upon support largely by special interest groups whose belief in the policy was motivated more by ideological arguments than concise analysis. Generally, neither movement garnered much support from academic economists, even those of similar political views. For example, the liberal Paul Krugman (1997) has been quite critical of the trade-labor linkage, not only due to the possibility that standards would result in protectionism, but also due to the economic implications of the standards themselves.
} 


\section{Acknowledgement}

The author thanks Robert Chase and an anonymous referee of this journal for very helpful comments.

Received 9 May 2002, Accepted 23 December 2002

\section{References}

Aggarwal, Mita (1995), International Trade, Labor Standards, and Labor Market Conditions: An Evaluation of the Linkages, Washington, DC: U.S. International Trade Commission.

Balistreri, Edward, Christine McDaniel and Eina Vivian Wong (2001), An Estimation of U.S. Industry-Level Capital-Labor Substitution Elasticities: Cobb-Douglas as a Reasonable Starting Point, USITC Economics Working Paper No. 2001-12-A.

Batra, Raveendra N. and Prasanta K. Pattanaik (1971), Factor Market Imperfections, the Terms of Trade, and Welfare, American Economic Review, 61, No. 5 (December), 946-955.

Cline, William R. (1997), Trade and Income Distribution, Washington, DC: Institute of International Economics.

Corden, W.M. and R. Findlay (1975), Urban Unemployment, Intersectoral Capital Mobility and Development Policy, Economica, 62, 59-78.

Davis, Donald and David Weinstein (1998), An Account of Global Factor Trade, National Bureau of Economic Research Working Paper No. 6785, Boston, Mass.: NBER.

Dollar, David, Edward N. Wolff, and William J. Baumol (1988), The Factor-Price Equalization Model and Industry Labor Productivity: An Empirical Test Across Countries, in Robert Feenstra (ed.), Empirical Methods for International Trade, Cambridge, Mass. and London: MIT Press.

Elliott, Kimberly Ann (2001), Fin(d)ing Our Way on Trade and Labor Standards?, International Economics Policy Briefs, Washington, DC: Institute of International Economics, No. PB01-5.

Feenstra, Robert C. (1980), Monopsony Distortions in an Open Economy: A Theoretical Analysis, Journal of International Economics, 10, (May), 213-235.

Fields, Gary S. and Earl L. Grinols (1991), Import Competition in the High-Wage Sector and Trade Policy Effects on Labor, Quarterly Review of Economics and Business, 31, No. 2, 33-56.

Fisher, Gordon (1995), Is There Such a Thing as an Absolute Poverty Line Over Time, Poverty Measurement Working Papers, Washington D.C.: U.S. Census Bureau.

Grossman, Gene M. (1984), International Competition and the Unionized Sector, Canadian Journal of Economics, 17, No. 3 (August), 541-556.

Harris, J.R. and M. Todaro (1970), Migration, Unemployment and Development: A Two 
Sector Analysis, American Economic Review, 60, 126-142.

International Labour Organization (1998), Proceedings of the Tripartite Meeting of Export

Processing Zones- Operating Countries, Geneva, Switzerland: September 28-

October 2.

International Labour Organization (2000), Minimum Wage Fixing in Mauritius, Labour Law and Labour Relations Branch Briefing Note No. 6.

International Labour Organization (2000b), Minimum Wage Fixing: A Summary of

Selected Issues, Labour Law and Labour Relations Branch Briefing Note No. 14.

Itoh, Motoshige and Kazuharu Kiyono (1987), Welfare-enhancing Export Subsidies, Journal of Political Economy, 95, 115-137.

Johnson, Harry G. (1966), Factor Market Distortions and the Shape of the Transformation Curve, Econometrica, 34, 686-698.

Johnson, Harry G. and Peter Mieszkowski (1970), The Effects of Unionization on the Distribution of Income: A General Equilibrium Approach, Quarterly Journal of Economics, 84, 539-561.

Jones, Ronald W. (1971), Distortions in Factor Markets and the General Equilibrium Model of Production, Journal of Political Economy, 79, May-June, 437-459.

Kim, Dae and Peter Mieszkowski (2001), The Effects of International Trade on Wage Inequality in the U.S., Working Paper.

Krugman, Paul (1995), Growing World Trade: Causes and Consequences, Brookings Papers on Economic Activity, 1, 327-362.

Krugman, Paul (1997), What Should Trade Negotiators Negotiate About? Journal of Economic Literature, 35, March, 113-120.

Lee, Thea (2001), Comments before the Economic Strategy Institute: Washington, DC, February 1.

Magee, Stephen P. (1973), Factor Market Distortions, Production, and Trade: A Survey, Oxford Economic Papers, 25, No. 1 (March), 1-43.

Maskus, Keith E. (1997), Should Core Labor Standards Be Imposed Through International Trade Policy, Washington, DC: World Bank Policy Research Paper \# 1817.

McCulloch, Rachel and Janet L. Yellen (1980), Factor Market Monopsony and the Allocation of Resources, Journal of International Economics, 10, (May), 237-247.

Morici, Peter and Evan Schulz (2001), Labor Standards in the Global Trading System,

Washington, DC: Economic Strategy Institute.

Organization for Economic Co-operation and Development (1999), Non-OECD

Countries and Multilateral Trade Liberalization: A Background Note on Some

Issues, Paris, France: OECD.

Penn World Tables. http://cansim.epas.utoronto.ca.

Pfluger, Michael (2001), Trade, Capital Mobility, and the German Labour Market, Weltwirtschaftliches Archiv, 137, No. 3, 473-500.

Rodrik, Dani (2001), The Global Governance of Trade as if Development Really

Mattered, A paper prepared for the United Nations Development Programme.

Swinnerton, Kenneth (1997), An Essay on Economic Efficiency and Core Labor 
Wage Differentials, Monopsony Labor Markets, and the Trade-Labor Standards Debate 161

Standards, The World Economy, 20, No. 1, 73-86.

Trefler, Daniel (1995), The Case of the Missing Trade and Other HOV Mysteries, American Economic Review, 85, 1029-46.

U.S. Labor Department (2000), Wages, Benefits, Poverty Line, and Meeting Workers' Needs in Apparel and Footwear Industries of Selected Countries, Washington D.C.

Wood, Adrian (1994), North-South Trade, Employment and Inequality, Oxford U.K.: Clarendon Press. 